\title{
TWENTIETH-CENTURY GLACIER CHANGE AT SVARTISEN, NORWAY: THE INFLUENCE OF CLIMATE, GLACIER GEOMETRY AND GLACIER DYNAMICS
}

\author{
by
}

Wilfred $\mathrm{H}$. Theakstone

(University of Manchester, School of Geography, Manchester M13 9PL, England)

\section{ABSTRACT}

In the $1870 \mathrm{~s}$ and $1880 \mathrm{~s}$, after a long period of cold conditions, most of the glaciers of Svartisen ended near their maximum Neoglacial limit. Subsequent changes, although principally a response to the climatic controls of mass balance, have been influenced by glacier geometry, including area/altitude relations and aspect, and by glacier dynamics. Calving has played a principal role in the decrease of size of two of the larger glaciers, Austerdalsisen and Flatisen, both of which became unstable once the grounded distal sections of their tongues lost contact with their beds. Mass balance variations reflect climatic controls of the length of the accumulation and ablation seasons, as well as changes of summer temperature. The mass balance record of Engabreen, a maritime outlet of the Vestre Svartisen ice cap, monitored since 1970 by the Norwegian Water Resources and Energy Administration, is not representative of the area as a whole: the more continental glaciers of Østre Svartisen are likely to experience negative net balances when that of Engabreen is slightly or moderately positive. However, the pattern of year-to-year changes of net balance is similar, not only for the Svartisen area as a whole, but also for a larger area.

\section{INTRODUCTION}

The consequences of changes of glacier size with time are important locally, as they affect exploitable water resources, and globally, in their influence on sea level change (Meier, 1984). Glaciers are sensitive to atmospheric variations of "greenhouse" gases, such as carbon dioxide (Oerlemans, 1986) and, because the climatic impact of increasing levels of atmospheric carbon dioxide may be greatest at high latitudes, the Arctic may be a sensitive indicator of fluctuations over a much wider area (Kelly and others, 1982). Accordingly, monitoring glacier change at the latitude of the Arctic Circle is desirable.

Svartisen, which lies between $66^{\circ} 31^{\prime} \mathrm{N}$ and $66^{\circ} 46^{\prime} \mathrm{N}$ (Fig. 1), is northern Scandinavia's largest ice-covered area. The hydroelectric power schemes which make use of water issuing from its glaciers are being expanded. The highest parts of both the Vestre Svartisen ice cap $\left(c a .220 \mathrm{~km}^{2}, 40\right.$ outlet glaciers) and the Østre Svartisen ice cap (ca. $145 \mathrm{~km}^{2}$, 20 outlet glaciers) are close to the sides of the narrow valley, Vesterdalen, which separates them. Nunatak peaks rise above the upper limit of permanent snow cover ( $c a$. $1500 \mathrm{~m}$ ). Two-thirds of Svartisen's glaciers terminate between 1000 and $700 \mathrm{~m}$, but six, all of them larger than $10 \mathrm{~km}^{2}$, descend below $500 \mathrm{~m}$ (Theakstone, 1988); Engabreen, the major outlet of Vestre Svartisen, where mass balance studies have been carried out since 1970 by the Norwegian Water Resources and Energy Administration (Laumann and others, 1988), now ends at about $40 \mathrm{~m}$. The diversity of size, aspect and area/altitude relations of the glaciers has resulted in markedly different 20th century responses to mass balance variations.

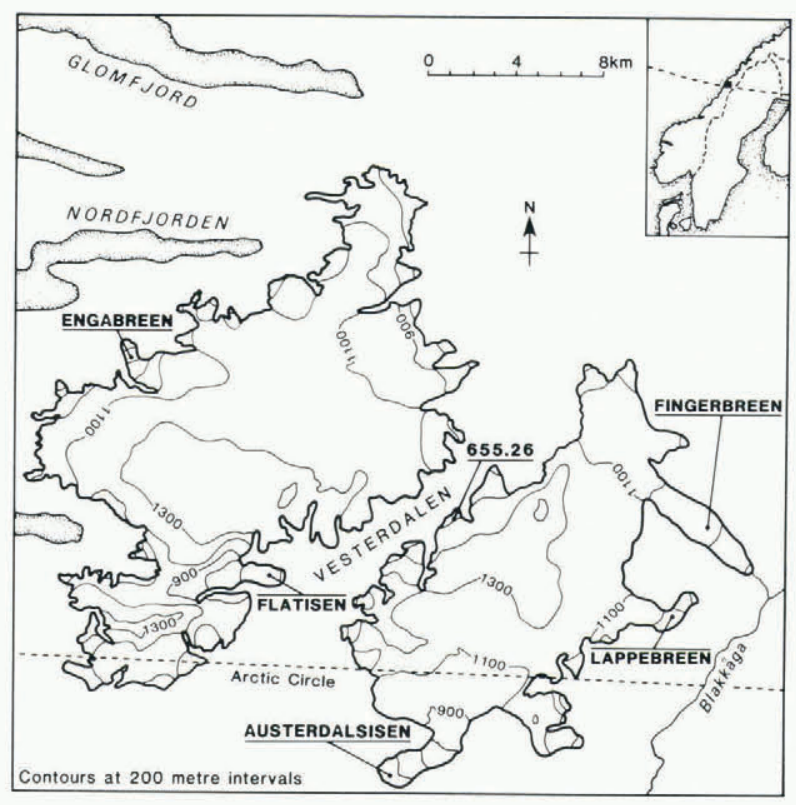

Fig. 1. The Vestre and Østre Svartisen ice caps and their outlet glaciers.

The first official maps of Svartisen (scale 1: 100 000), published by Norges Geografiske Oppmáling, were based on surveys carried out between 1894 and 1905. Aerial photographs taken by the Royal Air Force (United Kingdom) in 1945 have been used in the production of photogrammetric maps by the author's colleagues at Aarhus University, Denmark. Aerial photographs taken in 1968 were the basis of maps (1:50 000) published by Norges Geografiske Oppmåling. Since 1970, the author and Aarhus University colleagues have made repeated photogrammetric surveys of a number of the Svartisen glaciers (e.g. Knudsen and Theakstone, 1984; Theakstone and Knudsen, 1986).

\section{THE CLIMATE OF THE SVARTISEN AREA}

During the six winter months November-April, most precipitation at Svartisen falls as snow; that which falls in July and August generally is of rain. In transition months (winter-summer: May and June; summer-winter: September and October), precipitation is of rain in warmer periods but of snow when the temperature is lower. Although precipitation is known to vary with altitude as well as with location in relation to the coast, values for most of Svartisen are scarce. On the basis of glacier mass balance and river discharge data, Pettersson (1981) calculated that Vestre Svartisen receives $90-100 \%$ of Engabreen's winter precipitation, whilst Østre Svartisen receives less than $90 \%$. 
There are no permanent high-altitude meteorological stations at Svartisen. Between 1973 and 1981, the Norwegian Water Resources and Energy Administration maintained a summer station ("Skjaeret") at $1361 \mathrm{~m}$ on Vestre Svartisen. Temperature variations there were similar to those at Glomf jord $(39 \mathrm{~m})$, but Glomfjord temperatures were of the order of $10^{\circ} \mathrm{C}$ higher. The Glomf jord station (Fig. 1) has been in operation since 1916, but at Bodø (ca. $20 \mathrm{~m})$, another coastal site some $60 \mathrm{~m}$ further north, records started in 1868. Statistical analyses by the author indicate that Bodø air temperature data can be used to extend the Glomfjord record, permitting examination of variations during the past 120 years.

The 1870s and 1880s were cold: mean annual and winter temperatures were lower than in any subsequent decade (Table I). While the summers of the 1890s and 1900s were cooler than those of the two previous decades, warmer winters were reflected in higher mean annual temperatures. The summers of the 1910s were distinctly warmer, but cold winters resulted in low mean annual temperatures. The 1920s were warmer than any previous decade, and the 1930s even warmer, with mean annual temperatures more than $1{ }^{\circ} \mathrm{C}$ above those of the late 19th century. These trends were reflected in both winter and summer temperatures, the 1930s having higher values than any prior or subsequent decade. The winters of the 1940 s were more than $1{ }^{\circ} \mathrm{C}$ colder than those of the 1930 s and, although the summers remained warm, mean annual temperatures fell markedly from their peak. Mean annual and winter values stayed above the long-term average through the 1950s, 1960s and 1970 s, but summer temperatures, after remaining high in the 1950 s, fell markedly, the 1960s having cooler summers than any decade since the 1900s. The mean summer temperatures of the 1980 s have been even lower.

In contrast to the general pattern of winter and summer temperatures at Svartisen, those of May have displayed a rising tendency during the present century, interrupted only in the $1940 \mathrm{~s}$ and $1950 \mathrm{~s}$ (Table I). The mean May temperature in the 1980 s has been more than $1{ }^{\circ} \mathrm{C}$ above its pre-1960s level. Octobers also have become generally warmer: mean temperatures, having increased by the order of $1{ }^{\circ} \mathrm{C}$ between the $1920 \mathrm{~s}$ and 1930s, have remained above their long-term average. Clearly, the frequency of days with snowfall at the start and end of winter has decreased substantially during the last seventy years, thereby decreasing the length of the accumulation season at Svartisen.

\section{TH CENTURY GLACIER CHANGE AT SVARTISEN}

A hundred years ago, almost all the Svartisen glaciers ended close to their maximum Neoglacial extent, which they may have attained in the mid-18th century. Subsequent changes of the glaciers have been documented in the 3-volume Glacier Atlas (Theakstone, 1988). Little dateable material has been found within or beneath the moraine ridges marking the glaciers' outer limits. It is possible that the recent maximum almost coincided with a previous one of greater age.

Engabreen, which descends north-westwards from the Vestre Svartisen ice cap is Svartisen's best-documented glacier: a map and detailed sketches of it made in 1865 (Geikie, 1866) are the first reliable representation of Svartisen.

Frequent measurements of marginal change between 1883 and 1891 were followed by annual recording of the position of the terminus from 1909 until 1943. A glacier advance began in 1903. In 1910, the lake which had existed at the front for several years was no longer present, but it re-formed during the retreat phase which began the following year. In 1931, the glacier front began to break up by calving; its position in 1932 was very similar to that of 1865. Engabreen retreated from the lake (Engabrevatnet, $5 \mathrm{~m}$ a.s.l.) in 1944, and in 1950 ended some $200 \mathrm{~m}$ from it (Theakstone, 1988). Having retreated a further $140 \mathrm{~m}$, the glacier began to readvance in 1965 , and by 1984 was within $180 \mathrm{~m}$ of Engabrevatnet.

Most other glaciers of Svartisen have exhibited 20th century patterns of behaviour different from that of Engabreen. Mass loss has been greatest at two glaciers which end in lakes, Flatisen, the principal eastward-flowing outlet of Vestre Svartisen, and Austerdalsisen, which descends south-westwards from the southern limit of Østre Svartisen (Fig. 1). In 1890 Flatisen crossed Vesterdalen, broadening out in a fan shape in the valley bottom and rising up the eastern slope (Rekstad, 1893). In 1910 it still crossed Vesterdalen, but its lower part was thinner, and there was a small lake at the up-valley margin (Marstrander, 1911). Between 1922 and 1925, as the glacier thickness continued to decrease, Flatisen lost contact with the eastern slope of Vesterdalen. Until the mid-1930s the tongue remained grounded, but it then began to retreat rapidly as a result of calving. In 1945 the lake (Bjørnefossevatnet, $293 \mathrm{~m}$ ) between the glacier and the east side of Vesterdalen was about $1 \mathrm{~km}$ long. In 1957 it was

TABLE I. DEVIATIONS $\left({ }^{\circ} \mathrm{C}\right)$ OF DECADAL MEAN TEMPERATURES FROM THEIR OVERALL MEAN. (SUMMER: JULY-AUGUST; WINTER: NOVEMBER-APRIL).

$\begin{array}{lccccccc} & \text { Year } & \text { Winter } & \text { Summer } & \text { May } & \text { October } & \text { June } & \text { September } \\ 1870 \mathrm{~s} & -0.65 & -0.85 & -0.40 & -1.05 & -0.65 & 0.10 & -0.20 \\ 1880 \mathrm{~s} & -0.70 & -0.55 & -0.10 & -0.65 & -0.90 & 0.00 & 0.80 \\ 1890 \mathrm{~s} & -0.15 & -0.10 & -0.65 & 0.05 & -0.60 & -0.05 & -0.15 \\ 1900 \mathrm{~s} & -0.50 & -0.40 & -1.15 & -1.20 & -0.35 & -0.60 & -0.20 \\ 1910 \mathrm{~s} & -0.40 & -0.50 & 0.15 & -0.25 & -1.05 & -0.15 & -0.60 \\ 1920 \mathrm{~s} & 0.30 & 0.35 & 0.50 & 0.10 & -0.70 & -0.60 & 0.40 \\ 1930 \mathrm{~s} & 1.00 & 1.25 & 1.55 & 0.30 & 0.80 & 0.20 & 0.25 \\ 1940 \mathrm{~s} & 0.20 & 0.00 & 0.15 & -0.15 & 0.35 & 0.05 & -0.20 \\ 1950 \mathrm{~s} & 0.40 & 0.30 & 0.55 & -0.25 & 1.20 & 0.00 & 0.40 \\ 1960 \mathrm{~s} & 0.30 & 0.25 & 0.00 & 0.65 & 0.95 & 0.45 & 0.65 \\ 1970 \mathrm{~s} & 0.20 & 0.25 & -0.15 & 0.85 & 0.25 & 0.75 & -0.90 \\ 1980 \mathrm{~s} & 0.00 & 0.05 & -0.60 & 1.55 & 0.65 & -0.15 & -0.25\end{array}$




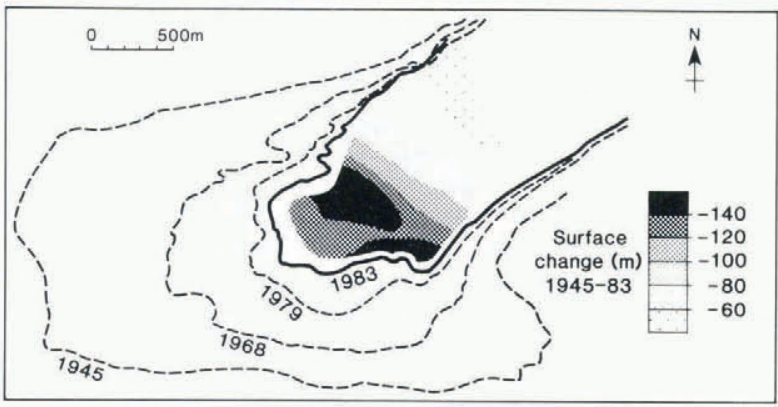

Fig. 2. Changes of position of the margins and of the thickness of the glacier Austerdalsisen, 1945-83.

$1.5 \mathrm{~km}$ long, in $19682.2 \mathrm{~km}$, and in 1985 more than $3 \mathrm{~km}$. Flatisen apparently still terminates in deep water; continued break-up, with further enlargement of Bjørnefossvatnet, seems inevitable.

A lake, Austerdalsvatnet, began to form at the western margin of Austerdalsisen between 1890 and 1897. By the mid-1930s, the edge of the glacier was floating and icebergs were calving from it. In 1945, the lake surface area was $1.9 \mathrm{~km}^{2}$, and in 1954 , when the glacier margin was more than $2.5 \mathrm{~km}$ from its 1897 position, it was $3.6 \mathrm{~km}^{2}$. In 1982 , Austerdalsisen lost contact with the bedrock at the southern side of the lake basin; its lower part broke up rapidly, retreating more than $100 \mathrm{~m}$ across the basin in one week (Theakstone and Knudsen, 1986). In 1983, the thickness of the grounded section of the glacier at the foot of the icefall was $140 \mathrm{~m}$ less than in 1945 (Fig. 2). In the 1987 snowmelt season, as the level of Austerdalsvatnet $(208 \mathrm{~m})$ was rising, the floating tongue which remained in the lake broke up. As the glacier now has almost left the lake basin, rapid retreat rates are unlikely to continue. The decrease of surface area of Austerdalsisen as a result of calving between 1945 and 1988 was of the order of $2.5 \mathrm{~km}^{2}$. In the lower part of the icefall $(c a .500 \mathrm{~m})$, the mean rate of decrease of ice thickness slowed during the 1950s, 1960s and 1970s, but increased again in the early 1980s.

The straight, $5 \mathrm{~km}$-long, south-east facing tongue of Fingerbreen, the longest glacier of Østre Svartisen, lacks marked changes of surface gradient; after widening from $950 \mathrm{~m}$ to $1450 \mathrm{~m}$ in the upper half, it narrows downglacier.

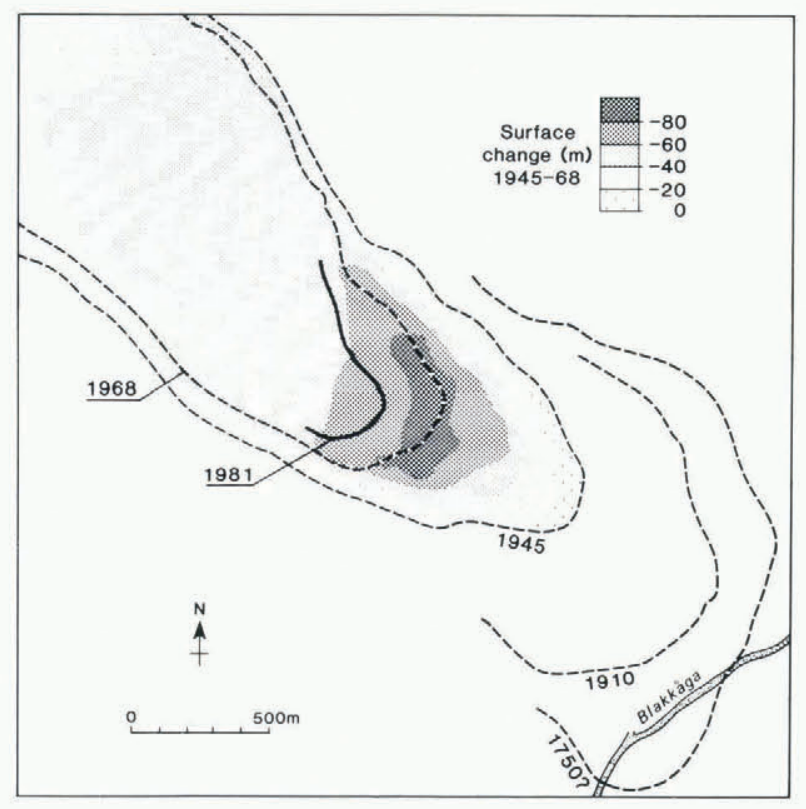

Fig. 3. Changes of position of the margins of the glacier Fingerbreen, 1910-81, and of ice thickness, 1945-68. The position of the Neoglacial maximum terminal moraine (1750?) is shown also.

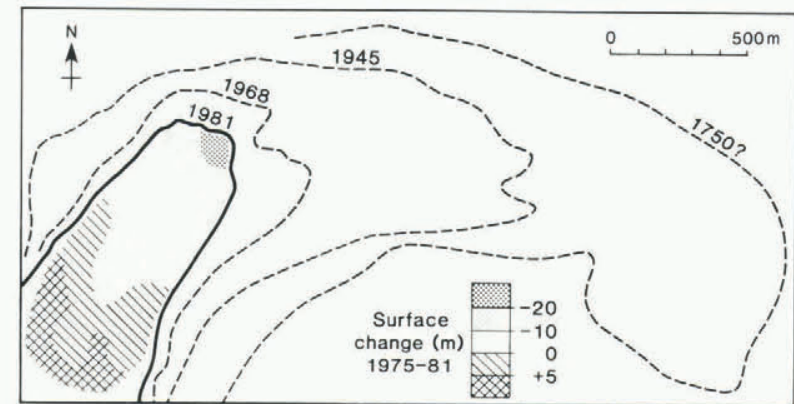

Fig. 4. Changes of position of the margins of the glacier Lappebreen, 1945-81, and of ice thickness, 1975-81. The position of the Neoglacial maximum terminal moraine (1750?) is shown also.

In 1882, Fingerbreen extended beyond the valley which confines most of its tongue; it ended a little short of the river Blakkảga (Fig. 1), some $200 \mathrm{~m}$ from the outermost terminal moraine, part of which was at the other side of the river. Between 1882 and 1890 little net change occurred. In 1910, the glacier ended some $200 \mathrm{~m}$ from the Blakkaga. In the next two years, it advanced $50-60 \mathrm{~m}$. No further observations were documented until 1945, when aeria photographs showed the glacier ending about $850 \mathrm{~m}$ from the Blakkåga. Retreat between 1945 and 1968 totalled $600 \mathrm{~m}$ Since 1970 the rate of retreat has decreased. About $1.5 \mathrm{~km}$ from the glacier front, the mean surface velocity was almost $50 \%$ higher between 1976 and 1981 than between 1971 and 1976 (Knudsen and Theakstone, 1984). Fingerbreen now ends more than $1500 \mathrm{~m}$ from the Blakkàga (Fig. 3), and is confined within a steep-sided valley, with consequent effects on the energy balance at its surface. There is no known record of any marked re-advance of Fingerbreen since 1912, but minor till ridges attest to frequent small-scale winter advances. Although 20th century retreat has been accompanied by steepening of the glacier front (now at about $450 \mathrm{~m}$ ), the surface gradient above $600 \mathrm{~m}$ has varied little.

Lappebreen, supplied by an accumulation area adjacent to that of Fingerbreen, is very broken, one icefall descending south-eastwards from the edge of the Østre Svartisen plateau and another, which includes a $90^{\circ}$ change of flow direction towards the north-east, extending to the terminus; the glacier narrows progressively from the lower limit of the accumulation area $(\mathrm{ca} .1100 \mathrm{~m})$. Between 1910 and 1945 Lappebreen retreated some $500 \mathrm{~m}$. In 1968 the terminus was on the slope facing the lower icefall, $950 \mathrm{~m}$ behind its 1945 position. The rate of ice loss below $600 \mathrm{~m}$, particularly rapid in the period $1968-75$, decreased after 1975. In 1981 Lappebreen appeared to be advancing; its thickness in the icefall had increased, and the terminus $(510 \mathrm{~m})$ was close to the position which it had occupied six years earlier, some $1100 \mathrm{~m}$ from the 1945 position (Fig. 4).

Whilst the larger glaciers of Svartisen have plateau-like accumulation areas, and most have tongues confined within valleys, several small, steep glaciers bordering Vesterdalen originate in cirque-like basins at relatively high altitude, their headwalls partly submerged by ice. They appear to respond quickly to mass balance variations, and most of them advanced between 1968 and 1985. In 1890, some of these small glaciers reached the river Glomaga, in the bottom of Vesterdalen. One of them, Glacier 655.26 (Fig. 1), which ended a few metres from the river in 1910, was about $450 \mathrm{~m}$ from it in 1945 . By 1968 the glacier's front had retreated to a position some $700 \mathrm{~m}$ from the river. Subsequently, however, its lower part thickened; in 1981 several rock outcrops which had broken the surface thirteen years before were completely covered by the ice. In 1985 Glacier 655.26 ended within $600 \mathrm{~m}$ of the Glomága.

\section{GLACIER MASS BALANCE VARIATIONS}

Because the roles of air temperature, precipitation, glacier location and topography cause values of both accumulation and ablation to differ, annual net mass balance 
values differ between glaciers within an area. However, regional patterns of variation often are similar. Thus, although net balance values at Engabreen, which has a maritime regime, with higher accumulation than the more continental glaciers, especially those of Østre Svartisen, are not representative of Svartisen as a whole, annual changes of net balance at most of the Svartisen glaciers which terminate on land might be expected to display similar trends.

Since 1970-71 the nature of year-to-year mass balance changes at Engabreen has been similar to that at Álfotbreen, a maritime glacier in western Norway, $600 \mathrm{~km}$ south-southwest of Svartisen, and Storbreen, which lies $100 \mathrm{~km}$ east of Alfotbreen (Fig. 5). The data, reported annually by the Norwegian Water Resources and Energy Administration (e.g. Laumann and others, 1988) indicate that, since 1970, the net balance has been positive in 13 years at Engabreen, 10 years at Álfotbreen and 6 years at Storbreen.

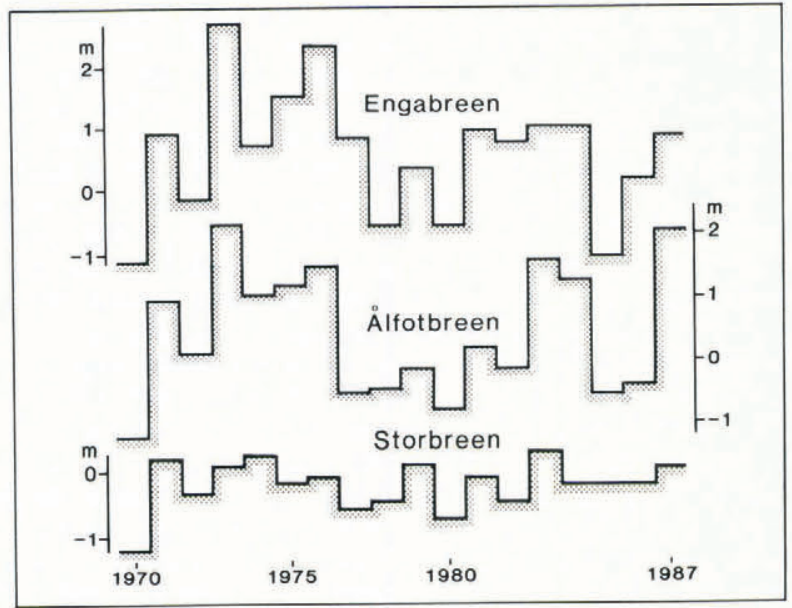

Fig. 5. Annual net mass balance ( $m$ water equivalent), 1970-87, at Engabreen, Ảlfotbreen and Storbreen. (Data from annual publications of the Norwegian Water Resources and Energy Administration.) The similarity of patterns of year-to-year changes, despite contrasts of actual values, reflects regional-scale climatic controls.

Whilst $80 \%$ of the area of Engabreen and $95 \%$ of Glacier 655.26 are above $1030 \mathrm{~m}$ (the mean equilibrium line altitude at Engabreen between 1970 and 1987), lower proportions of the larger Østre Svartisen outlets are above this level: $75 \%$ of Lappebreen, $70 \%$ of Austerdalsisen and $65 \%$ of Fingerbreen. These eastern glaciers receive less snowfall at equivalent altitudes, have high mean equilibrium line altitudes and experience negative annual net balances more frequently than does Engabreen. The influence of surface gradient and aspect on mass balance is reflected in the fact that, since 1945, the rate of decrease of thickness of the ablation area of Lappebreen has been much higher than that of the longer, less steep ablation area of Fingerbreen, despite their similar altitudes. Ablation rates in icefalls of different aspect also differ significantly: summer melting in the south-west facing icefall of Austerdalsisen exceeds that in the north-west facing icefall of Engabreen and the north-east facing icefall of Lappebreen.

\section{DISCUSSION AND CONCLUSIONS}

Glacier decline may occur as a result of an increase of summer temperature, decreased snowfall, or other combinations of warmer conditions and decreased snowfall. However, because changes of position of glacier fronts resulting from climatic controls are affected by glacier dynamics, they may lag behind mass balance changes by different periods, depending on the size, geometry and stability of the individual glaciers (Furbish and Andrews, 1984).
A detailed history by Kelly and others (1982) demonstrated the similarities of trends, fluctuations and extremes of Arctic temperatures for the period 1881-1980, over large areas. Such similarities have been characteristic of northern Europe since the mid-18th century. The hundred years prior to 1870 were cold, annual mean temperatures remaining low at Stockholm and Leningrad despite summer temperatures which were higher in the second half of the 18th century than during the period 1931-60; most winters were cold (Koutaniemi, 1987). Prolonged low temperatures would account for the Svartisen glaciers remaining close to their maximum Neoglacial size until they were first documented in detail in the third quarter of the 19th century. The changes which they have undergone during the last 120 years reflect climatic conditions which, in addition to their influence on summer and winter temperatures, have affected the relative lengths of the accumulation and ablation seasons, dependent in part on the temperatures of May, June, September and October.

Between 1880 and 1910 summer air temperatures at Svartisen declined, as did those of June and September. Between 1900 and 1915 several of the Svartisen glaciers advanced, but most changed little before the 1920s. Slow retreat of the larger tongues reflected a gradual decrease of their thickness. In the $1930 \mathrm{~s}$ temperatures were more than $1.5^{\circ} \mathrm{C}$ above those of the $1880 \mathrm{~s}$ in both winter and summer. October temperatures had increased by a similar amount, whilst those of May were almost $1{ }^{\circ} \mathrm{C}$ higher. By the 1930 s, when calving into marginal lakes began to contribute significantly to the mass balances of Engabreen, Austerdalsisen and Flatisen, general glacier retreat was apparent at Svartisen.

Although winters became $1{ }^{\circ} \mathrm{C}$ cooler between the $1930 \mathrm{~s}$ and the $1960 \mathrm{~s}$, whilst summers cooled by $1.5^{\circ} \mathrm{C}$, the duration of the ablation season increased as the temperatures of all the summer-winter and winter-summer transition months rose slightly. Most glaciers, including Engabreen, became markedly smaller between the mid-1930s and the mid-1960s.

Since the 1960s temperatures generally have fallen a little, but the increase of May temperatures, together with a rise of those of September and October from the end of the 1960s, indicates a continued shift to long-term warming in those periods, and a consequent lengthening of the ablation season. Engabreen has had a net positive balance since the start of the 1970 s and has been advancing for much of the last twenty years. The small glaciers above Vesterdalen also have advanced since the late 1960s, and the retreat of Lappebreen has slowed or ceased. Fingerbreen, however, has continued to retreat, albeit at a slower rate, accompanied by a marked increase of surface velocity in the 1970s.

Should the cooling trend of summer temperatures, apparent at Svartisen since the 1950s, continue, it might offset the tendency of warming transition months to increase the duration of the ablation season. However, the differing responses of the glaciers of Østre and Vestre Svartisen to present and possible future climatic conditions must be taken into account in plans to use the water discharging from the glaciers in generating hydroelectric power, as must the role of calving at those glaciers which terminate in lakes.

\section{ACKNOWLEDGEMENTS}

I recall with deep gratitude the hospitality of the late Anton and Asbjorg Svartisdal during annual visits to Svartisen over a period of more than thirty years. The company of $\mathrm{K}$. Westermark on many occasions has given me much pleasure, and the information about the glaciers of Svartisen which he has provided from his own extensive observations has been of great value. Mrs A. Wright, the late $\mathrm{K}$. Eggum and Mrs L. Mittigaard have done much to make my periods in the area both pleasant and rewarding. The company in the field of N.T. Knudsen and J.T. Møller has been an inspiration, and I thank both for their major contribution to the programme of photogrammetric surveying of Svartisen glaciers, and for the fruitful discussions which we have had. I am pleased to acknowledge financial support from the University of Manchester, the Natural Environment 
Research Council, the Royal Society, the British Council and Statens Naturvidenskabelige Forskningsrảd.

\section{REFERENCES}

Geikie, A. 1866. The old glaciers of Norway and Scotland. Proc. Roy. Soc. Edinburgh, 5, 530-556.

Kelly, P.M., P.D. Jones, C.B. Sear, B.S.G. Cherry and R.K. Tavakol. 1982. Variations in surface air temperatures: Part 2. Arctic Regions, 1881-1980. Monthly Weather Rev., 110, 71-83.

Knudsen, N.T. and W.H. Theakstone. 1984. Recent changes of some glaciers of East Svartisen, Norway. Geogr. Annaler, 66A, 367-380.

Koutaniemi, L. 1987. Little Ice Age flooding in the Ivaljoki and Oulankajoki valleys, Finland? Geogr. Annaler, 69A, 71-83.
Marstrander, R. 1911. Svartisen. Strøgets morfologi og braeerne. Archiv for Mathematik og Naturvidenskaberne, $31(8), 1-40$.

Meier, M.F. 1984. Contribution of small glaciers to global sea level. Science, 226, 1418-1421.

Oerlemans, J. 1986. Glaciers as indicators of a carbon dioxide warming. Nature, 320, 607-609.

Petterssen, L.E. 1981. Beregning av normalavløpet i Svartisen-området. Norges Vassdrags- og Elektrisitetsvesen Hydrologisk Avdeling Rapport, 3-81, 46-57.

Rekstad, J. 1893. Beretning om en undersøgelse af Svartisen, foretagen i somrene 1890 og 1891. Archiv for Mathematik og Naturvidenskab, 16, 266-321.

Theakstone, W.H. 1988. Svartisen Glacier Atlas. Manchester. Department of Geography, University of Manchester.

Theakstone, W.H. and N.T. Knudsen. 1986. Recent changes of a calving glacier, Austerdalsisen, Svartisen, Norway. Geogr. Annaler, 68A, 303-316. 